\title{
Rapid shifts in Atta cephalotes fungus-garden enzyme activity after a change in fungal substrate (Attini, Formicidae)
}

\author{
P. W. Kooij • M. Schiøtt • J. J. Boomsma • \\ H. H. De Fine Licht
}

Received: 12 May 2010/Revised: 8 October 2010/Accepted: 13 October 2010/Published online: 27 November 2010

(C) The Author(s) 2010. This article is published with open access at Springerlink.com

\begin{abstract}
Fungus gardens of the basidiomycete Leucocoprinus gongylophorus sustain large colonies of leaf-cutting ants by degrading the plant material collected by the ants. Recent studies have shown that enzyme activity in these gardens is primarily targeted toward starch, proteins and the pectin matrix associated with cell walls, rather than toward structural cell wall components such as cellulose and hemicelluloses. Substrate constituents are also known to be sequentially degraded in different sections of the fungus garden. To test the plasticity in the extracellular expression of fungus-garden enzymes, we measured the changes in enzyme activity after a controlled shift in fungal substrate offered to six laboratory colonies of Atta cephalotes. An ant diet consisting exclusively of grains of parboiled rice rapidly increased the activity of endo-proteinases and some of the
\end{abstract}

Electronic supplementary material The online version of this article (doi:10.1007/s00040-010-0127-9) contains supplementary material, which is available to authorized users.

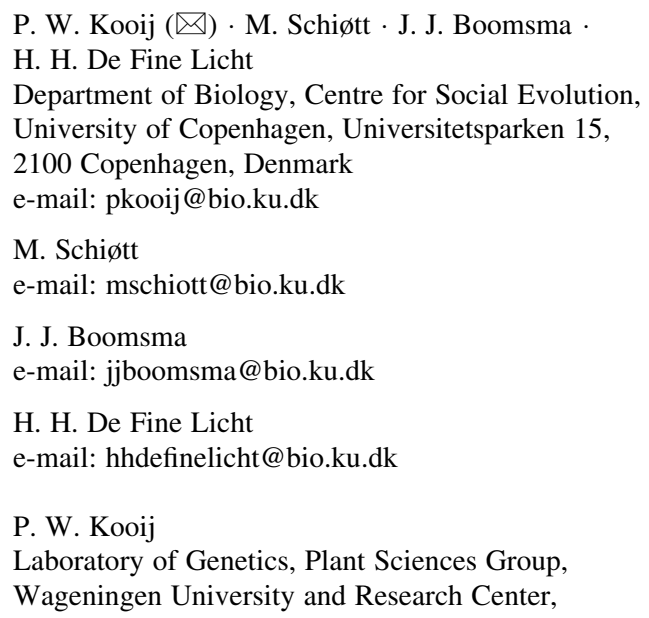

pectinases attacking the backbone structure of pectin molecules, relative to a pure diet of bramble leaves, and this happened predominantly in the most recently established top sections of fungus gardens. However, fungus-garden amylase activity did not significantly increase despite the substantial increase in starch availability from the rice diet, relative to the leaf diet controls. Enzyme activity in the older, bottom sections of fungus gardens decreased, indicating a faster processing of the rice substrate compared to the leaf diet. These results suggest that leaf-cutting ant fungus gardens can rapidly adjust enzyme activity to provide a better match with substrate availability and that excess starch that is not protected by cell walls may be digested by the ants rather than by the fungus-garden symbiont.

Keywords AZCL assay - Leucocoprinus gongylophorus . Enzyme activity $\cdot$ Mutualism $\cdot$ Plant degradation

\section{Introduction}

Leaf-cutting ants maintain characteristic fungus gardens inside their nest that they supply with fragments of leaves, fruit and other fresh plant material. The mutualism is obligatory for both the symbiotic fungus and the ants (Mueller et al., 2005), as the fungus is dependent on the ants for substrate provisioning and control of competing and pathogenic microbes (Currie et al., 1999; Hart et al., 2002; Valmir Santos et al., 2004), whereas the ants are dependent on the fungus as their main food component (Weber, 1966; Littledyke and Cherrett, 1976; Quinlan and Cherrett, 1979).

The most highly advanced and complex agricultural systems are found in the leaf-cutting ant genera Atta and Acromyrmex (Weber, 1966; Mueller et al., 2001; Mueller 
et al., 2005), which evolved 8-12 million years ago (Schultz and Brady, 2008) and are characterized by mainly collecting fresh plant material (De Fine Licht and Boomsma, 2010). Atta and Acromyrmex workers carry freshly cut leaves to the nest where they process this material into substrate for their crop symbiont Leucocoprinus gongylophorus, by chewing it into minute pieces that are mixed with "saliva". These leaf pieces are deposited on the outer edges of the top section of the garden, after which fragments of mycelium are added, together with fecal fluid that contains fungal enzymes that have survived gut passage, to assist with initial substrate degradation (Boyd and Martin, 1975; Quinlan and Cherrett, 1977; Bass and Cherrett, 1994; Erthal et al., 2009). While the fungus garden degrades this plant material, it eventually produces inflated hyphal tips (gongylidia) that are preferentially eaten by the ants before the old mycelium is removed from the bottom sections of the garden (Bass and Cherrett, 1995; Schiøtt et al., 2008).

The consecutive breakdown of plant material implies that specific sections can be recognized as representing different stages of plant degradation: a top section that is often relatively darker in color because of an excess of (usually green) leaf substrate and still sparse growth of new antinoculated tufts of mycelium; a middle section with denser mycelial growth where most of the gongylidia are produced and most of the ant brood is kept (Weber, 1972); a bottom section with very dense mycelial growth where most of the plant material has been degraded and the exhausted mycelium is discarded by the ants (Weber, 1966). These consecutive sections can be easily recognized in laboratory colonies kept in cylindrical containers to emulate the shape of natural gardens (see below) and also in natural colonies upon excavation (De Fine Licht and Boomsma, 2010), although the relative size of the different sections is assumed to be somewhat dependent on seasonal shifts in foraging activity.

Recent studies have shown that enzyme activity differs between the sections in a leaf-cutting ant fungus garden (Schiøtt et al., 2008) and that pectinases are particularly active in the early stages of degradation, presumably to dissociate the pectin matrix between the harder cell wall fibers to allow the proteinases and amylases to degrade the inner contents of the plant cells (De Fine Licht et al., 2010). The cross-linking glycans (hemicelluloses) that connect cellulose microfibrils are usually not degraded until the material is located in the middle and lower parts of the fungus garden, whereas the cellulose microfibrils are not disassociated and unlikely to be degraded until they are deposited in the refuse pile and exposed to a specific bacterial community (Gomes de Siqueira et al., 1998; D'Ettorre et al., 2002; Schiøtt et al., 2008; Erthal et al., 2009; De Fine Licht et al., 2010; Scott et al., 2010). The ants themselves are able to break down and digest starch, chitin, proteins and simple sugars (D'Ettorre et al., 2002; Erthal et al., 2004; Richard et al., 2005; Erthal et al., 2007) and thus largely express complementary enzyme profiles to the fungus garden (D'Ettorre et al., 2002; Richard et al., 2005; Erthal et al., 2009).

In the present study, we measured the dynamics of enzyme activity across the three different sections of fungus gardens of the laboratory colonies of Atta cephalotes, following a controlled shift in ant diet, to test the hypothesis that fungus gardens have evolved some degree of plasticity in enzyme production in response to a diverse range of natural substrates, not only of fresh plant material, but also of dry plant material, insect feces, seeds, flowers and fruit (Price et al., 2003; De Fine Licht and Boomsma, 2010). Specifically, we asked: (1) whether enzyme activity in the fungus garden responds in a predictable way to changes in fungal substrate that increases starch and protein availability; (2) how fast fungus gardens can make such adjustments to new forage; and (3) whether the activity of other enzymes is decreased when substrate nutrients are biased relative to normal forage.

\section{Materials and methods}

\section{Ant colonies and feeding regimes}

Six queenright colonies of Atta cephalotes (Attini: Myrmicinae: Formicidae) were used in the experiments. All colonies were maintained in climate rooms with standard conditions of ca. $25^{\circ} \mathrm{C}$ and ca. $70 \%$ relative humidity and a standard laboratory diet of bramble leaves, rice grains and apple. At the onset of the experiment, three colonies (1: ACe-X-BB, 2: ACe-2008-22, 3: ACe-19-BB) were chosen randomly and henceforth provided with a diet of only bramble leaves, whereas three other colonies (4: ACe-10-BB, 5: ACe-21-BB, 6: ACe-16-BB) were provided with a diet of only parboiled rice. All six colonies were measured for enzyme activity (see below) just before the diet was changed $\left(t_{0}\right)$ and then measured every third day for a total 30 days (Fig. 1), i.e., on the same days that fresh food was provided. The bramble leaf diet resembles the natural diet and is the standard one used to maintain laboratory colonies at the University of Copenhagen, so it served as control treatment in the experiment. The rice diet has a higher amount of starch and proteins and a lower amount of cellulose compared to bramble leaves (Table 1). Bramble leaves have a complex structure and contain many components, which can be degraded by the fungal symbiont, even though they also contain defensive anti-herbivory compounds such as tannins (Selvendran, 1984; Chapin III and Shaver, 1988), although these do not appear to affect colony growth under laboratory conditions. The huskless rice 


\section{A}

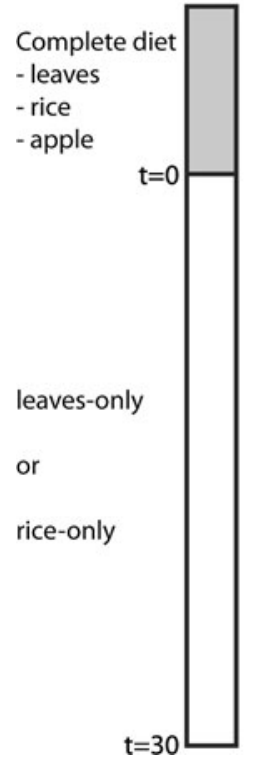

Fig. 1 The experimental setup used in this study. Fungus-garden samples were taken at $t_{0}$ prior to the experimental treatment, after colonies had been fed with a mixed laboratory diet of bramble leaves, rice grains and pieces of apple (a). At $t_{0}$ three colonies were randomly assigned to a diet of only bramble leaves and three other colonies to a diet of only parboiled rice (a, b). Every third day until day 30 , fungal
C

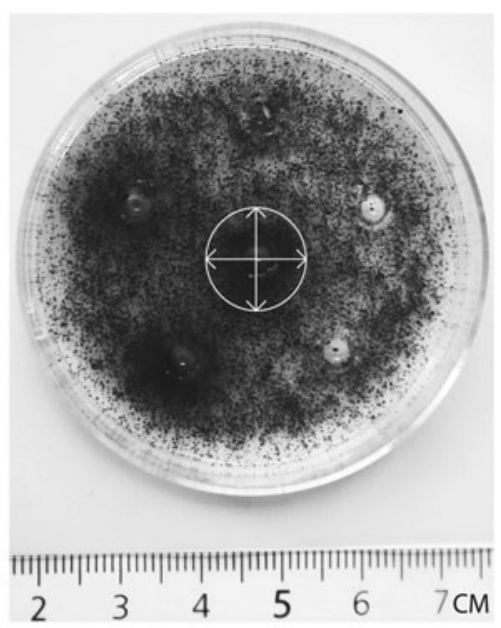

Table 1 Main carbon sources in the experimental diets and their expected degradation enzymes

\begin{tabular}{lll}
\hline Diet & Main constituents & Assumed degrading enzymes measured in this study \\
\hline $\begin{array}{l}\text { Rice grains } \mathrm{s}^{\mathrm{a}, \mathrm{b}} \\
\text { Bramble leaves }^{\mathrm{b}, \mathrm{c}}\end{array}$ & $\begin{array}{l}\text { Starch, hemicelluloses, proteins; no distinct cell walls } \\
\text { Cellulose and hemicelluloses associated with } \\
\text { cell walls; starch and proteins inside the cells }\end{array}$ & $\begin{array}{c}\alpha \text {-Amylase, endo-proteinases, endo-xylanases, } \beta \text {-glucanase } \\
\text { Cellulases, xyloglucanase, } \alpha \text {-amylase, endo-proteinases, } \\
\text { endo-xylanases, } \beta \text {-glucanase }\end{array}$ \\
\hline
\end{tabular}

The lack of distinct cell walls and the relative higher amounts of starch and proteins in rice were expected to induce a higher enzyme activity of fungal amylases and proteinases in the fungus garden

${ }^{\mathrm{a}}$ Champagne et al. (2004), ${ }^{\mathrm{b}}$ Selvendran (1984), ${ }^{\mathrm{c}}$ Chapin III and Shaver (1988)

grains, on the other hand, provide energy-rich and easily degradable "packages" that can be cut into pieces by the ants. These grains do not have defensive chemical compounds, but potentially have nutritional deficiencies that would preclude long-term sustainable maintenance of attine fungus gardens (Champagne et al., 2004).

\section{Enzyme extraction}

From each of the six colonies, two replicate fungus-garden samples were taken every third day from the surface of each of the three sections (top, middle and bottom) and from the debris pile. This yielded eight samples per colony consisting of two replicate samples per section that were evaluated separately. Enzymes were extracted using previously published methods (Rønhede et al., 2004; De Fine Licht et al., 2010). Fungus-garden material ( $120 \mathrm{mg}$ ) was crushed with samples were collected from each colony with two samples collected from the top-, middle- and bottom sections of gardens and from the debris pile, respectively, and immediately measured for enzyme activity on AZCL assay plates (c) following standard methods (see text for details) (Photo: Pepijn Kooij) a pestle in a $1.5-\mathrm{ml}$ Eppendorf tube containing $500 \mu \mathrm{l}$ of $0.05 \mathrm{M}$ TRIS-HCl buffer ( $\mathrm{pH}$ 7.0). Immediately after collection, samples were vortexed and then centrifuged for $15 \mathrm{~min}\left(15,000 \mathrm{~g}\right.$ at $\left.4^{\circ} \mathrm{C}\right)$ and the supernatant, now containing the enzymes, was subsequently removed and kept on ice until further analysis $(<30 \mathrm{~min})$.

\section{Enzyme assays and screening}

The extracts were tested for enzyme activity on 12 different Azurine-crosslinked (AZCL) substrates: amylose, casein, collagen, debranched arabinan, rhamnogalacturonan, galactomannan, galactan, HE-cellulose, barley $\beta$-glucan, xyloglucan, xylan and arabinoxylan that were chosen because these substrates yielded positive enzyme activities in an earlier study (De Fine Licht et al., 2010). Enzyme activities were measured following standard conditions as described 
earlier (Schiøtt et al., 2008; De Fine Licht et al., 2010). Briefly, assay plates were prepared for each substrate using an agarose medium (1\% agarose, $23 \mathrm{mM}$ phosphoric acid, $23 \mathrm{mM}$ acetic acid, $23 \mathrm{mM}$ boric acid) and the $\mathrm{pH}$ adjusted for each substrate according to the manufacturer's description (Megazyme, Bray, Ireland). Test plates were made from $0.1 \mathrm{~g} / \mathrm{l} \mathrm{AZCL}$ substrate, which was poured in 6-cm Petri dishes. After the medium had solidified, round wells (area of ca. $0.1 \mathrm{~cm}^{2}$ ) were made in each plate with a cut-off pipette tip. For the samples from the top, middle and bottom sections, $12 \mu \mathrm{l}$ of the supernatant was applied in each well in duplicate. For the samples of the debris pile, $6 \mu \mathrm{l}$ of the supernatant was applied in the wells in duplicate. After $22 \mathrm{~h}$ of incubation at $25^{\circ} \mathrm{C}$, the plates were photographed and the area of the blue halo surrounding each well [which is a quantitative measure for the amount of enzyme activity (Hasper et al., 2004; Schiøtt et al., 2008; Pedersen et al., 2009; De Fine Licht et al., 2010)] was measured using the software program ImageJ ver. 1.41 for Macintosh (Fig. 1). The average halo area of the two duplicate samples collected from each garden section and colony was calculated and used in further analysis as a single data point.

\section{Statistical analysis}

The differences over time in enzyme activity between the two diets were examined using an ANOVA for repeated measures (RMD) in JMP ver. 7.0.2 for Macintosh. Factors included in the model as predictors of enzyme activity were: (1) diet, either rice or bramble leaves; (2) time, days since the onset of the experiment, and (3) the interaction of diet with time. Because of insufficient degrees of freedom, the assumption of sphericity could not be tested explicitly, so that approximate Huynh-Feldt estimates of epsilon (Winer et al. 1991) were used to correct for possible biases. The data were also analyzed using a split-plot design $\left(R^{2}\right.$ between $0.55-0.90$ ), which gave similar results as the repeated measures ANOVA (data not shown).

\section{Results}

The complete results of the AZCL measurements are given in the Supplementary Online Material. In the top sections of fungus gardens where the initial degradation takes place, endo-protease (casein: $F_{8,32}=2.3945, p=0.0388$; collagen: $\left.F_{10,40}=4.9202, p=0.0001\right)$ and pectinase activity (rhamnogalacturonan: $F_{9,34}=2.4500, p=0.0297$ ) rapidly increased in the colonies provided with the rice diet, relative to the leaf-diet controls, and remained high throughout the experiment, although this was not significant for endoprotease measured with casein. Also $\alpha$-amylase activity changed significantly with time during the experiment
$\left(F_{10,40}=2.3162, p=0.0294\right)$, but the excess activity of this enzyme in the top section was less pronounced and not significant $\left(F_{10,40}=0.0642, p=0.8125\right)$ compared with the leaf diet. Apart from a gradual increase in endo-xylanase activity (arabinoxylan: $F_{7,30}=3.1114, p=0.0119$ ), all remaining enzyme activities measured in the top section of the fungus garden did not change throughout the experiment (see Supplementary Online Material).

Except for three pectinases (debranched arabinan, galactan and rhamnogalaturonan) and two endo-proteinases (casein and collagen), all other enzymes gradually decreased in mean activity toward the bottom section of the fungus gardens, although these decreases were not significant as they were always associated with substantial increases in variance (see Supplementary Online Material). To increase the generality and power of tests, we focused on specific mean enzyme activities at day 30 relative to day 0 , and we combined the 12 enzymes into five functional groups: proteinases, amylase, cellulases, xylanases and pectinases (Fig. 2). This produced a clear difference in enzyme activity between the three different fungus-garden sections and the debris pile. All functional groups showed increased activity in the top-middle sections and decreased activity in the bottom-debris pile sections following the shift in diet from rice to bramble leaves (Fig. 2), but the rate at which this happened and the extent of difference varied across the functional groups. Proteinases and amylase had a higher activity in the top section and reduced enzyme activity directly afterward. The activity of cellulases was only slightly increased, but lasted through the middle section, similar to xylanases. Pectinases, however, had an increased activity throughout all three sections of the fungus gardens (Fig. 2).

\section{Discussion}

Efficient enzymatic degradation of plant material is crucially important for nourishment in leaf-cutting ant colonies. The choice of substrate by fungus-growing ants of different genera was recently shown to have affected enzyme activity of fungus gardens over an evolutionary timescale (De Fine Licht et al., 2010). The present study supplements these insights by evaluating the degree of plasticity in enzyme expression in response to short-term changes in forage in a single species, A. cephalotes. We used an unusual and artificial diet of only rice to confront the ant symbiont with the equivalent of "easy fast food" enriched in protein and carbohydrates and found that such diet shift does indeed change the enzyme profiles expressed by fungus gardens in a section-specific way that appears to reflect the rate of decomposition. Leaf-cutting ants collect a wide spectrum of food items that require many extracellular 


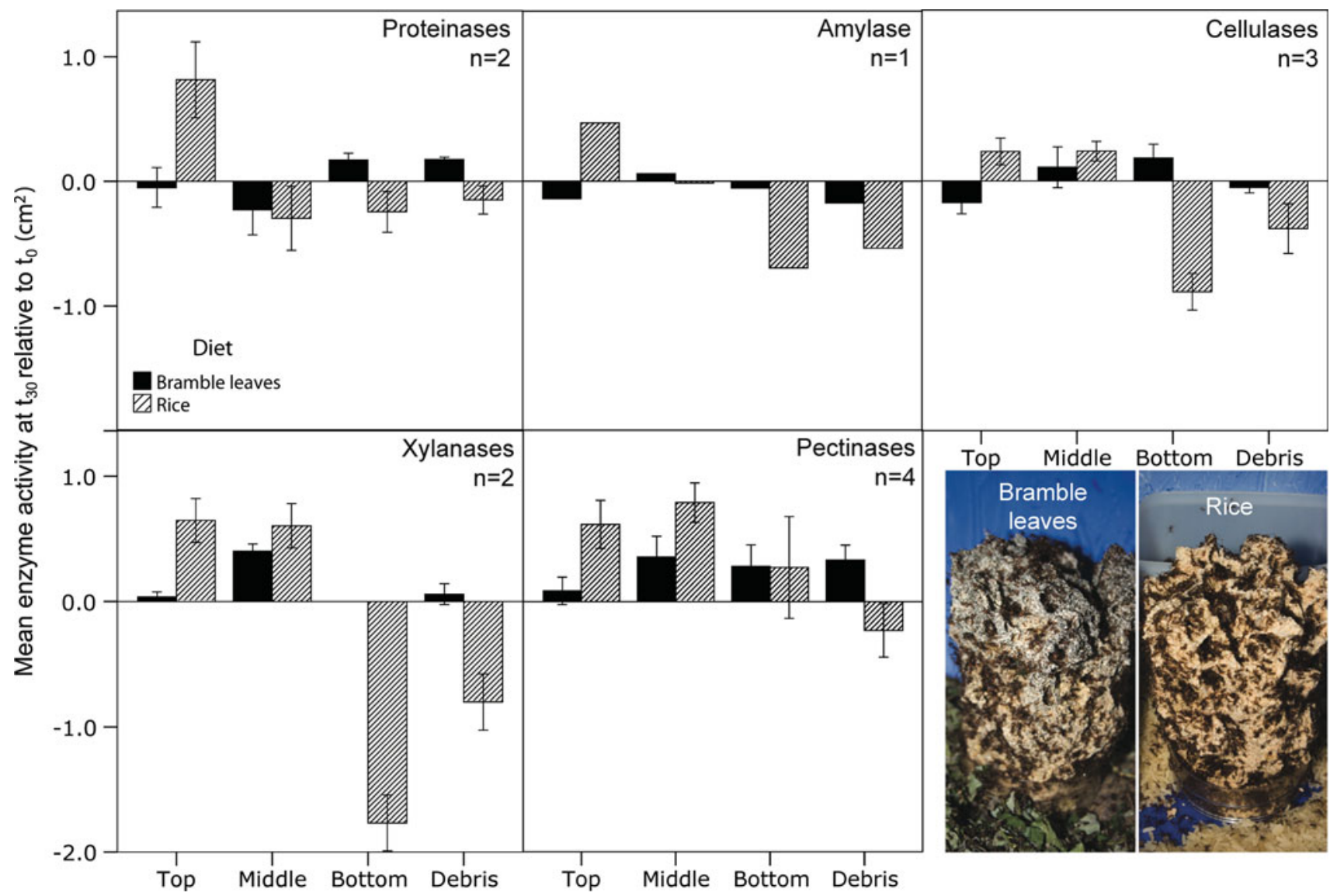

Fig. 2 Mean enzyme activities $( \pm \mathrm{SE})$ at day $30\left(t_{30}\right)$ relative to the onset of the experiment $\left(t_{0}\right)$ per functional enzyme group and fungusgarden section, based on 1-4 AZCL substrates per group of enzymes (see Supplementary Online Material). In all five enzyme groups the rice-induced activity increased in the top sections and decreased in the bottom section and debris pile, relative to the bramble leaf diet. The pictures toward the bottom right are representative examples of the macroscopically visible differences in color and texture between fungus gardens provided with only bramble leaves (left) and only rice diet (right) after 15 days, i.e., halfway through the experiment (photos: Pepijn Kooij) fungus-garden enzymes to optimize substrate utilization (De Fine Licht and Boomsma, 2010). The parboiled rice-only diet that we provided had two major resource enrichments, starch and protein (Table 1), which produced interestingly different degrees of change.

The main component of rice is starch (Champagne et al., 2004), but despite the elevated influx of starch associated with the rice-based diet, the $\alpha$-amylase activity of fungus gardens did not appear to increase substantially in the top sections of the fungus garden (see Supplementary Online Material). This may be because the level of $\alpha$-amylase activity in natural fungus gardens of Acromyrmex and Atta leafcutter ants is already elevated relative to the gardens of their Trachymyrmex and Sericomyrmex ant sister clades, possibly as a general adaptation to the active leaf-cutting habit (De Fine Licht et al., 2010). Although a more substantial sample size might have shown that these smaller differences were real (e.g., the patterns between proteinases and amylase in Fig. 2 are similar, but only a single amylase substrate was used so that the latter enzyme activities had no error bars), the ants might have also already ingested and digested most of the starch using the $\alpha$-amylases from their labial glands (D'Ettorre et al., 2002; Erthal et al., 2004; Erthal et al., 2007). This would be consistent with the notion that adult leafcutter ants also directly ingest plant sap and fruit juice (Littledyke and Cherrett, 1976) and would imply that the ants can extend this habit to any source of starch that is not contained in hard cell walls that their fungal symbiont needs to breach first. If excess starch would be processed in this way, the increased concentration of glucose might then affect the production of fungal amylase by some antinduced feedback mechanism (Silva et al., 2006a, b). Such conditional inhibition scenarios have previously been proposed for cellulases and xylanases produced in fungus gardens (Silva et al., 2006a; Schiøtt et al., 2008), because filamentous fungi generally ensure that decomposition enzymes are produced only when the end product of the catalytic reaction is in limited supply. 
It is much less clear to what extent adult leaf-cutting ants produce substantial amounts of proteinases themselves (Erthal et al., 2004, 2007), as the production of protein degrading enzymes might compromise the efficiency of fungal enzyme transfer via the fecal droplets to newly established top sections of gardens (Poulsen and Boomsma, 2005; Schiøtt et al., 2008). If constraints of this kind exist, it would possibly explain our finding that fungal enzyme reactions to the enhanced protein content of rice, relative to bramble leaves, were consistently positive. Provisioning with fungal enzymes via fecal droplets may thus be the ants' way of assisting the fungus garden in rapidly acquiring an optimal enzyme activity profile for the amount of substrate present. The rapid changes we observed in protease and rhamnogalacturonase activity in the top section (see Supplementary Online Material) may thus have been facilitated by increased fecal droplet production by the ants, because fecal droplets are known to contain several proteases and pectinases (Rønhede et al., 2004).

The overall patterns in Fig. 2 indicate that a diet shift to rice grains reduced enzyme activity in the bottom of fungus gardens for essentially all functional groups of degradation enzymes. With ad libitum provisioning, as carried out in these experiments, this might imply that the ants would tend to discard old fungus-garden material earlier relative to the controls in which they used bramble leaves as fungal substrate. After 30 days of using only rice as substrate, the fungus gardens in our experiment had indeed shrunk substantially (P. W. Kooij, pers. obs.), but we only realized this after the experiments had been completed and so measurements were not available. However, we cannot exclude that the rice-only diet imposed other nutrient deficiencies that may have reduced fungal growth or functioning after some time.

Rapid fungal enzyme activity responses to increased resource availability in the top section of fungus gardens are likely to be adaptive, because the L. gongylophorus fungusgarden symbiont competes with other microbes that might otherwise gain unwelcome growth advantages (Scott et al., 2010). This was underlined in our laboratory experiments by rice diets, increasing the likelihood of mite infestations in the provisioning boxes of our colonies. Although our results illustrate that rice only is a highly artificial diet, it is also clear that the ants are eager to exploit rice grains when they are provided in addition to bramble leaves and pieces of apple, as this combination has been a highly appropriate standard diet for our laboratory colonies for many years. This raises the question why the collection of grass seeds, which would have at least some of the same protein and starch contents as rice grains, is not more common in fungus-growing ants.

It is known that diverse types of seeds and seed husks are collected by almost all genera of fungus-growing ants under natural conditions (Leal and Oliveira, 2000), but seeds appear to make up a vanishingly small proportion of the total plant material collected (Price et al., 2003; De Fine Licht and Boomsma, 2010). Even in grass-cutting attine species where the ants might be expected to encounter grass seeds more easily, seed collection has hardly been observed (W. O. H. Hughes, pers. obs.). This is remarkable, as other ant genera such as Pogonomyrmex, Messor and Pheidole have specialized in seed harvesting (Johnson, 2001). This suggests that grass seeds, as exemplified by rice grains in our study, are unlikely to be a long-term sustainable substrate for the clades of fungi that are domesticated by attine ants, possibly because they lack a full complement of nutrients to sustain garden growth (Champagne et al., 2004). As the C/N ratio of rice is very high, it is tempting to hypothesize that grass seeds are deficient in nitrogen to act as good fungal substrates, even in ant fungus gardens that have recently been shown to derive a significant part of their proteins from nitrogen-fixing bacteria (Pinto-Tomas et al., 2009).

Acknowledgments The authors thank the Smithsonian Tropical Research Institute (STRI), Panama, for providing logistic help and facilities to work in Gamboa, and the Autoridad Nacional del Ambiente y el Mar (ANAM) for permission to sample ants in Panama and to export them to Denmark.

Open Access This article is distributed under the terms of the Creative Commons Attribution Noncommercial License which permits any noncommercial use, distribution, and reproduction in any medium, provided the original author(s) and source are credited.

\section{References}

Bass M. and Cherrett J.M. 1994. The role of leaf-cutting ant workers (Hymenoptera, Formicidae) in fungus garden maintenance. Ecol. Entomol. 19: 215-220

Bass M. and Cherrett J.M. 1995. Fungal hyphae as a source of nutrients for the leaf-cutting ant Atta sexdens. Physiol. Entomol. 20: 1-6

Boyd N.D. and Martin M.M. 1975. Faecal proteinases of the fungusgrowing ant, Atta texana: their fungal origin and ecological significance. J. Insect Physiol. 21: 1815-1820

Champagne E.T., Wood D.F., Juliano B.O. and Bechtel D.B. 2004. The rice grain and its gross composition. In: Rice: Chemistry and Technology, $3^{\text {rd }}$ Ed (Champagne E.T., Ed). American Association of Cereal Chemists Inc, St. Paul, Minnesota. pp 77-107

Chapin III F.S. and Shaver G.R. 1988. Differences in carbon and nutrient fractions among Arctic growth forms. Oecologia 77: 506-514

Currie C.R., Scott J.A., Summerbell R.C. and Malloch D. 1999. Fungus-growing ants use antibiotic-producing bacteria to control garden parasites. Nature 398: 701-704

De Fine Licht H.H., Schiøtt M., Mueller U.G. and Boomsma J.J. 2010. Evolutionary transitions in enzyme activity of ant fungus gardens. Evolution 64: 2055-2069

De Fine Licht H.H. and Boomsma J.J. 2010. Forage collection, substrate preparation and diet composition in fungus-growing ants. Ecol. Entomol. 35: 259-269

Erthal Jr. M., Silva C.P. and Samuels R.I. 2004. Digestive enzymes of leaf-cutting ants, Acromyrmex subterraneus (Hymenoptera: Formicidae: Attini): distribution in the gut of adult workers and partial characterization. J. Insect Physiol. 50: 881-891 
Erthal Jr. M., Silva C.P. and Samuels R.I. 2007. Digestive enzymes in larvae of the leaf cutting ant, Acromyrmex subterraneus (Hymenoptera: Formicidae: Attini). J. Insect Physiol. 53: 1101-1111

Erthal Jr. M., Silva C.P., Cooper R.M. and Samuels R.I. 2009. Hydrolytic enzymes of leaf-cutting ant fungi. Comp. Biochem. Phys. B 152: 54-59

D'Ettorre P., Mora P., Dibangou V., Rouland C. and Errard C. 2002. The role of the symbiotic fungus in the digestive metabolism of two species of fungus-growing ants. J. Comp. Physiol. B 172: $169-176$

Gomes de Siqueira C., Bacci Jr. M., Pagnocca F.C., Bueno O.C. and Hebling M.J.A. 1998. Metabolism of plant polysaccharides by Leucoagaricus gongylophorus, the symbiotic fungus of the leafcutting ant Atta sexdens L. Appl. Environ. Microb. 64: 4820-4822

Hart A.G., Bot A.N.M. and Brown M.J.F. 2002. A colony-level response to disease control in a leaf-cutting ant. Naturwissenschaften 89: $275-277$

Hasper A.A., Trindade L.M., Van Der Veen D., Van Ooyen A.J.J. and De Graaff L.H. 2004. Functional analysis of the transcriptal activator XlnR from Aspergillus niger. Microbiol-SGM 150: 1367-1375

Johnson R.A. 2001. Biogeography and community structure of North American seed-harvester ants. Annu. Rev. Entomol. 46: 1-29

Leal, I.R. and Oliveira, P.S., 2000. Foraging ecology of attine ants in a neotropical savanna: seasonal use of fungal substrate in the cerrado vegetation of Brazil. Insect. Soc. 47: 376-382

Littledyke, M. and Cherrett, J.M., 1976. Direct ingestion of plant sap from cut leaves by the leaf-cutting ants Atta cephalotes (L.) and Acromyrmex octospinosus (Reich) (Formicidae: Attini). B. Entomol. Res. 66: 205

Mueller U.G., Schultz T.R., Currie C.R., Adams R.M.M. and Malloch D. 2001. The origin of the attine ant-fungus mutualism. $Q$. Rev. Biol. 76: 169-197

Mueller U.G., Gerardo N.M., Aanen D.K., Six D.L. and Schultz T.R. 2005. The evolution of agriculture in insects. Аnпи. Rev. Ecol. Evol. S 36: 563-595

Pedersen M., Hollensted M., Lange L. and Andersen B. 2009. Screening for cellulose and hemicellulose degrading enzymes from the fungal genus Ulocladium. Int. Biodeter. Biodegr. 63: 484-489

Pinto-Tomas A.A., Anderson M.A., Suen G., Stevenson D.M., Chu F.S., Cleland W.W., Weimer P.J. and Currie C.R. 2009. Symbiotic nitrogen fixation in the fungus gardens of leaf-cutter ants. Science 326: 1120

Poulsen M. and Boomsma J.J. 2005. Mutualistic fungi control crop diversity in fungus-growing ants. Science 307: 741-744

Price S.L., Murkami T., Mueller U.G., Schultz T.R. and Currie C.R. 2003. Recent findings in fungus-growing ants: evolution, ecology, and behavior of a complex microbial symbiosis. In: Genes, Behaviors and Evolution of Social Insects (Kikuchi T, Azuma N and Higashi S, Eds). Hokkaido University Press, Sapporo. pp 255-280

Quinlan R.J. and Cherrett J.M. 1977. The role of substrate preparation in the symbiosis between the leaf-cutting ant Acromyrmex octospinosus (Reich) and its food fungus. Ecol. Entomol. 2: 161170

Quinlan R.J. and Cherrett J.M. 1979. The role of fungus in the diet of the leaf-cutting ant Atta cephalotes (L). Ecol. Entomol. 4: 151160

Richard F.J., Mora P., Errard C. and Rouland C. 2005. Digestive capacities of leaf-cutting ants and the contribution of their fungal cultivar to the degradation of plant material. J. Comp. Physiol. B 175: $297-303$

Rønhede S., Boomsma J.J. and Rosendahl S. 2004. Fungal enzymes transferred by leaf-cutting ants in their fungus gardens. Mycol. Res. 108: 101-106

Schiøtt M., De Fine Licht H.H., Lange L. and Boomsma J.J. 2008. Towards a molecular understanding of symbiont function: identification of a fungal gene for the degradation of xylan in the fungus gardens of leaf-cutting ants. BMC Microbiol. 8: 40

Schultz T.R. and Brady S.G. 2008. Major evolutionary transitions in ant agriculture. P. Natl. Acad. Sci-Biol. 105: 5435-5440

Scott J.J., Budsberg K.J., Suen G., Wixon D.L., Balser T.C. and Currie C.R. 2010. Microbial community structure of leaf-cutter ant fungus gardens and refuse dumps. PloS ONE 5: e9922

Selvendran R.R. 1984. The plant cell wall as a source of dietary fiber: chemistry and structure. Am. J. Clin. Nutr. 39: 320-337

Silva A., Bacci Jr. M., Pagnocca F.C., Bueno O.C. and Hebling M.J.A. 2006a. Starch metabolism in Leucoagaricus gongylophorus, the symbiotic fungus of leaf-cutting ants. Microbiol. Res. 161: 299-303

Silva A., Bacci M., Pagnocca F.C., Bueno O.C. and Hebling M.J.A. 2006b. Production of polysaccharidases in different carbon sources by Leucoagaricus gongylophorus Moller (Singer), the symbiotic fungus of the leaf-cutting ant Atta sexdens Linnaeus. Curr. Microbiol. 53: 68-71

Valmir Santos A., Dillon R.J., Dillon V.M., Reynolds S.E. and Samuels R.I. 2004. Occurrence of the antibiotic producing bacterium Burkholderia sp. in colonies of the leaf-cutting ant Atta sexdens rubropilosa. FEMS Microbiol. Lett. 239: 319-323

Weber N.A. 1966. Fungus-growing ants. Science 153: 587-604

Weber N.A. 1972. Gardening ants, the attines. American Philosophical Society, Philadelphia. $146 \mathrm{pp}$

Winer B.J., Brown D.R. and Michaels K.M. 1991. Statistical Principles in Experimental Design. McGraw-Hill, New York. 928 pp 